\title{
IDEOLOGI DAN EPISTEMOLOGI KITAB TUHFAT AL- RÂGHIBIIN KARYA MUHAMMAD ARSHAD AL-BANJARI
}

\author{
M. Rusydi \\ Institut Agama Islam Negeri Antasari Banjarmasin, Indonesia \\ E-mail: madibiqbal@yahoo.com
}

\begin{abstract}
Tubfat al-Râghibin is the first book of theology for Banjarese besides the book of Usûl al-Din. This book focuses not on the area of surface-structure (outer aspects) but particularly on the deep-structure area (inner aspects). The deep-structure study will help interpret the meaning of the book in its relation to the historical, social, and political context. This paper will explore the deep-structure area which consists of two problems, namely the ideology and the epistemology of Tuhfat al-Râghibinn. This study concludes that the ideology of the book is Sunnî, and the epistemology of the book is bayant. It is based on an analysis that the source of the book is text (nass.s), its method is qiyâs and ijtihâd, and the rational argument in the book is used as a means of justification, although it still maintains a balance between revelation and rationalism. In addition, the type of argument is defensive-apologetic, the validity of its argument is the conformity of text to the reality, while the basic principle is infisâl (discontinuance) and tajwîz (permissiveness).
\end{abstract}

Keywords: Tuhfat al-Râghibîn, ideology, epistemology, Sunnî.

\section{Pendahuluan}

Kitab Tuhfat al-Râghibin adalah kitab tauhid pertama selain kitab Usû́l al-Dîn yang ditulis Muhammad Arshad al-Banjari setelah pulang dari studi selama kurang lebih 35 tahun di Haramayn, pada bulan Ramadhan 1186 H./Desember 1772 M. Kitab Tuhfat al-Râghibîn merupakan kitab yang ditulis oleh al-Banjari atas permintaan Sultan Banjar yang bernama Tamjidillah untuk menjelaskan masalah keimanan. ${ }^{1}$

${ }_{1}^{1}$ Shaykh Muhammad Arshad bin Abdullah al-Banjari, Tuhfah al-Râghibîn (Martapura: YAPIDA, 2000), 2. 
Jika dikomparasikan antara kitab Usûl al-Din dan kitab Tuhfat alRâgbibîn, maka kitab Ușûl al-Dîn lebih diperuntukkan bagi masyarakat awam sehingga uraiannya lebih praktis, sementara Tuhfat al-Râgbibin ditujukan untuk kalangan intelektual dan pihak kerajaan sehingga isinya secara teoretis lebih detail dibandingkan kitab Ușul al-Dîn. Kitab Tubfat al-Râghibin cenderung dikaji secara filologis dan teologis, sehingga terkesan kaku dan tidak variatif. Selain itu, kitab ini masih kalah populer dibandingkan kitab Sabîl al-Mubtadîn al-Banjari.

Jadi, jika diperhatikan, penelitian kitab Tuhfat al-Râghibin selama ini cenderung dilihat pada wilayah fisiknya atau surface-structure (struktur luar), belum menyentuh wilayah deep-structure (struktur dalam). Dari segi surface-structure, Tubfat al-Râghibîn memang bisa dilihat dari segi tulisan, bahasa, sistematika kitab, dan lain sebagainya. Hal ini mudah untuk diidentifikasi, karena surface-structure bisa diindera. Namun dari segi deep-structure cukup rumit untuk dilihat, sebab untuk mengungkap wilayah ini diperlukan analisis dan pemahaman konstruksi sistem yang meliputinya di masa kemunculan dan relasinya dengan teks. Dengan mengungkapkan hubungan dua hal ini akan memungkinkan ditemukannya makna yang lebih luas tentang keberadaan kitab ini.

Oleh karena itu, kitab ini menarik untuk dikaji lebih lanjut pada ranah deep-structure-nya, terutama pada wilayah ideologi dan epistemologi yang meliputinya, sebab di samping wilayah ini masih minim dikaji, hal ini juga mampu membantu memaknai kehadiran kitab ini secara lebih luas dalam sejarah keberagamaan masyarakat Banjar.

\section{Ajaran Pokok Kitab Tuḥfat al-Râghibîn}

1. Pengantar Kitab

Kitab ini dimulai dengan menyebutkan nama Allah yang dilanjutkan dengan pujian kepada-Nya dan doa keselamatan serta rahmat untuk Nabi Muhammad, keluarga dan sahabat-sahabatnya. Pada bagian pengantar ini, Muhammad Arshad al-Banjari menginformasikan bahwa penulisan kitab ini dilakukan pada tahun 1188 H./1774 M. karena diminta oleh pembesar saat itu. Ada kemungkinan, pembesar yang dimaksud adalah raja sebab ia menyatakan bahwa tidak bisa menolak permintaan tersebut. ${ }^{2}$

${ }^{2}$ Ibid.

476 ISLAMICA, VOLUME 8, NOMOR 2, MARET 2014 


\section{Hakikat Iman}

Pada bagian ini, al-Banjari menekankan iman secara tașdîq hati. Ikrar lisan dengan dua kalimat shahâdat dianggap bukanlah bagian dari hakikat iman, tetapi hanya sebuah syarat untuk melakukan perbuatanperbuatan yang ada dalam hukum Islam. ${ }^{3}$ Ia juga berpendapat bahwa amal saleh hanya penyempurna keimanan. ${ }^{4}$ Ia juga berbicara tentang relasi iman dan Islam dengan menyatakan bahwa Islam tidak akan ada tanpa iman, iman akan berkurang tanpa Islam. ${ }^{5}$

3. Hal-hal yang Merusak Keimanan

Pada bagian ini, al-Banjari menunjukkan hal-hal yang dapat merusak keimanan atau menjadikan orang murtad (riddah) dari segi perbuatan, ucapan atau keyakinan baik disengaja, bermain-main ataupun karena memang mengingkari Islam itu sendiri. ${ }^{6}$

Selain uraian tentang perbuatan, perkataan dan gurauan yang mengandung kekafiran, pada bagian ini ia juga menunjukkan aliran yang dianggapnya benar (iktikad Ahl al-Sunnah wa al-Jamâ'ah) dan aliran yang dianggapnya salah baik secara teologis maupun sufistik. Di bagian ini, ia juga mengritik tradisi masyarakat Banjar, yaitu; upacara manyanggar banua (menyelamati desa dengan memberi makan orang gaib) dan mambuang pasilih (membuang sial), dan mengategorikannya dalam bid'ah dalalah. Kemudian, ia juga melarang untuk bersahabat dengan jin.

4. Kemurtadan dan Hukumnya

Pada bagian ini, al-Banjari menunjukkan tiga syarat terjadinya murtad, hukuman orang murtad dan orang yang berhak menghukumnya, serta status jenazah orang murtad.

5. Dosa dan Taubat

a. Dosa

Menurut al-Banjari, bertaubat dari segala dosa hukumnya wajib. Siapa yang memperlambat taubat maka ia berdosa. Dosa terbagi dua yakni dosa besar dan dosa kecil. Dosa besar adalah perbuatan maksiat yang mengakibatkan siksa yang berat di akhirat. Selanjutnya, ia memetakan 42 macam dosa besar.

\footnotetext{
3 Ibid., 3.

${ }^{4}$ Ibid., $4-5$.

${ }^{5}$ Ibid.

${ }^{6}$ Ibid., 7.
} 
b. Taubat

Menurut al-Banjari, rukun taubat dari dosa besar ada tiga, yakni; pertama, menyesali perbuatan maksiat yang telah dilakukan. Kedua, berhenti melakukan perbuatan maksiat saat itu juga. Ketiga, berniat tidak mengulangi perbuatan maksiat tersebut. ${ }^{7}$ Selanjutnya, pada bagian ini, ia juga menunjukkan cara-cara taubat dikaitkan dengan perbuatan maksiat yang dilakukan. Misalnya, jika maksiatnya berkaitan dengan hak sesama manusia seperti merampas harta, maka taubatnya selain memenuhi tiga rukun di atas, ia juga harus mengembalikan hak orang yang dirampasnya.

6. Afُâl al-Tbâd

Menurut al-Banjari, Ahl al-Sunnah wa al-Jamâ‘ah berkeyakinan bahwa semua tindakan manusia telah ditakdirkan Allah sejak zaman azali dengan kuasa dan kehendak-Nya yang qadìm (kekal). Adapun kuasa dan kehendak manusia bersifat baharu, sehingga tidak memberi bekas dalam mewujudkan semua perbuatannya. Meskipun demikian, manusia memiliki ikhtiar dan kasb. ${ }^{8}$ Kasb inilah yang menyebabkan manusia dibebani tanggung jawab untuk melakukan perbuatan baik dan menjauhi perbuatan buruk. Sebagai balasan, Allah memberikan pahala bagi yang taat, dan siksa bagi yang inkar.

Pada bagian ini, ia juga membahas pendapat perbuatan hamba menurut kaum Qadarîyah dan Jabarîyah sebagai pembanding dengan aliran Ahl al-Sunnah wa al-Jamâ'ah. Kemudian ia berkesimpulan bahwa aliran yang terakhir disebut berada di antara paham Qadarîyah dan Jabarîyah. Jika Qadarîyah menekankan perbuatan hamba sebagai kreasi manusia tanpa intervensi Tuhan, dan Jabarîyah menekankan perbuatan hamba sebagai kreasi Tuhan tanpa intervensi manusia, maka Ahl al-Sunnah wa al-Jamâ‘ah mengolaborasikan keduanya, yakni perbuatan hamba sebagai kreasi Tuhan tetapi manusia memiliki hak untuk berusaha dan berikhtiar.

\section{Ideologi dalam Kitab Tuḥfat al-Râghibîn}

1. Tauhid Sunnî Sebagai Ideologi Tụ̣fat al-Râghibîn

a. Tauhid Sunnî vis-a-vis Tauhid non-Sunnî

Dari seluruh uraian al-Banjari dalam kitab Tuhfat al-Râghibin dapat disimpulkan bahwa konstruksi ideologi yang hendak dibangunnya adalah ideologi Sunnî. Ideologi Sunnî dapat ditemukan ketika ia

\footnotetext{
${ }^{7}$ Ibid., 52.

${ }^{8}$ Ibid., 57. 
mendeksripsikan makna iman. Menurutnya, esensi iman adalah tasdîq, pembenaran dalam hati. Ikrar iman dengan lisan dan perbuatan bukanlah esensi iman. Iman dengan ikrar lisan hanya berfungsi untuk menunjukkan diberlakukannya hukum-hukum Islam kepada yang berikrar. Sementara perbuatan iman hanyalah tanda kesempurnaan iman. Jadi, seseorang boleh saja beriman tanpa beramal sebab yang membedakannya hanya masalah kesempurnaan. Jika beramal maka ia telah menyempurnakan imannya, dan jika tidak beramal maka imannya belum sempurna. Meskipun demikian, ia juga mengapresiasi definisi iman murakkab, yakni tasdîq, iman di dalam hati, dan ikrar dengan lisan. ${ }^{9}$

Konsepsi iman seperti ini terdapat pada aliran Sunnî. Misalnya, Imam al-Ash'arî dalam al-Luma', menyatakan bahwa iman adalah altasdîq. ${ }^{10}$ Dalam konteks esensi iman sebagai murakkab, sebenarnya adalah sikap terbuka al-Banjari terhadap pendapat ulama lain yang tergabung dalam aliran Sunnî seperti al-Baghdâdî, al-Bazdawî, dan alNasafî. Al-Baghdâdi, salah satu tokoh Sunnî, misalnya berpendapat bahwa iman adalah pengakuan dengan hati dan didasari pengetahuan. Pengetahuan tidak muncul kecuali setelah datangnya kabar dari wahyu Tuhan. ${ }^{11}$ Sementara al-Bazdawî berpendapat bahwa iman adalah ikrar dengan lisan dan pengakuan dengan hati. ${ }^{12}$ Kemudian, al-Nasafí berpendapat bahwa iman adalah pengakuan dengan hati atas apa yang dibawa oleh Nabi dari Allah dan mengikrarkannya. ${ }^{13}$

Dalam Tubfat al-Râghibîn, dia juga merujuk kepada tokoh-tokoh Sunnî seperti Shaykh Ibn Hajar dengan kitab Zawâhir 'an Iftirâ' alKabâir dan Kitab Tuhfat al-Muḅtâj li Sharḥ al-Minhâjj, Imam al-Ghazâlî dengan Minhâj al-'Âbidîn, Shaykh Mazjad dengan kitab Sharḅ al-'Ubab, Imam Ramlî dengan kitab Nihâyat al-Muḅtâj, Ibrâhîm al-Laqqanî dengan kitab Umdat al-Murîd: Sharḥ Jawhar al-Tawhî̉, Zakarîyâ alAnșârî dengan kitab Asnâ' al-Matâlib, dan Ismâ'îl b. Muqrî dengan

\footnotetext{
${ }^{9}$ Ibid., 4.

10 Abû Ḥasan 'Alî b. Ismâ'îl al-Ash'arî, Kitâb al-Luma' fî al-Radd 'alâ Abl al-Ziyagh wa al-Bida' (Mesir: Shirkah Mâhimah Muḍrîyah, 1955), 123. Sa'd al-Dîn al-Taftâzânî, Sharḥ al-'Aqâ'id al-Nasafîyah (Kairo: Maktabah al-Kulliyât al-Azharîyah, 1988), 109.

11 'Abd al-Qâhir al-Baghdâdî, Kitâb Usûll al-Dîn (Beirut: Dâr al-Âfâq al-Jadîdah, 1981), 249.

12 Abû al-Yasr al-Bazdawî, Usûl al-Dîn (Kairo: al-Maktabah al-Azharîyah li al-Turâth, 2003), 148.

13 'Umar b. Muhammad al-Nasafî, al-'Aqâiid al-Nasafîyah (t.t.: t.p., 537 H.), 4.
} 
kitab Rawdat al-Tâlib. Jadi, kecenderungan Sunnî, secara referensial cukup dominan. . $^{\dot{4}}$

Untuk mengetahui lebih jauh ideologi Sunnî dalam Tuhfat alRâghibîn, berikut dibandingkan dengan doktrin-doktrin dasar Sunnî. Doktrin pertama adalah sifat Tuhan. Menurut imam al-Ash'arî, Tuhan mempunyai sifat, sifat itu bukanlah Tuhan namun tidak lain dari Tuhan. ${ }^{15}$ Dengan kata lain, sifat Tuhan itu melekat pada zat Tuhan, sehingga sifat tergantung pada Tuhan namun Tuhan tidak tergantung pada sifat. Secara tersirat al-Banjari juga berpendapat bahwa Allah memiliki sifat, namun ia tidak menjelaskan lebih jauh bagaimana sifat Allah tersebut. Ia hanya berpendapat bahwa salah satu perbuatan murtad adalah meniadakan sifat Allah. ${ }^{16}$

Doktrin Sunnî kedua adalah al-kasb. Aliran Sunnî meski memiliki penafsiran yang berbeda-beda antar-tokohnya tentang relasi kuasa Tuhan dan al-kash, namun semuanya menyepakati manusia tidak menciptakan perbuatannya, kuasa manusia tidak berpengaruh dalam merealisir perbuatannya, karena kuasa dan kehendak manusia adalah ciptaan Allah. Meski demikian, manusia tetap memiliki al-kasb. Dalam kitab Tuhfat al-Râghibin, al-Banjari juga berpendapat manusia memiliki kash meski perbuatannya diciptakan oleh Allah. ${ }^{17}$

Doktrin Sunnî selanjutnya adalah mungkinnya melihat Allah (ru'yat Allâh). Al-Ash'arî menyatakan "di antara bukti bisa melihat Allah dengan mata kepala adalah bahwa tidak ada sesuatu zat yang ada kecuali Allah. Ketika Allah merupakan sesuatu zat yang ada, maka bisa saja Allah memperlihatkan diri-Nya kepada kita". ${ }^{18}$ Meskipun demikian, Allah dapat dilihat di akhirat namun tidak dapat dideskripsikan. ${ }^{19}$ Al-Banjari menyetujui pendapat di atas, bahwa Allah bisa dilihat dengan mata kepala di akhirat bukan di dunia ini. Oleh karena itulah, ia mengafirkan orang yang berpendapat bahwa Allah bisa dilihat di dunia ini. ${ }^{20}$

14 Pemetaan figur dan referensi bernuansa Sunnî, terutama fiqh Shâficîyah bisa dilihat dalam 'Abd al-Kâfî al-Subkî, Ṭabaqât al-Shâficî al-Kubrâ (Mesir: 'Îsâ Bâb alHạalabî, 1964).

15 Abû Hạan 'Alî b. Ismâ'îl al-Ash'arî, al-Ibânah 'an Ușûl al-Diyânah (t.t.: Dâr alDa'wah al-Salafiyah, 1992), 134-157.

16 al-Banjari, Tuḅfat al-Râghibîn, 7.

${ }^{17}$ Ibid., 57.

18 al-Ash'arî, al-Ibânah, 24-26.

${ }^{19}$ Ibid., 68-84.

${ }^{20}$ al-Banjari, Tuhfat al-Râghibin, 12 dan 24. 
Doktrin Sunnî lainnya sebagaimana dinyatakan al-Ash'arî adalah Tuhan mempunyai sifat antropomorfisme seperti mata, wajah, tangan serta bersemayam di 'Arsh, tetapi bilâ kayf, tidak bisa dideskripsikan seperti sifat jasmani dan kondisi manusia. ${ }^{21}$ Al-Banjari juga menyatakan hal serupa dalam Tuhfat al-Râgbibin. ${ }^{22}$

Doktrin Sunnî lain, menurut al-Baghdâdî dalam al-Farq bayn alFiraq adalah selain meyakini adanya telaga (al-bawḍ), jembatan (al-sirât. ), dan shafấât, juga mengakui keabsahan kekhalifahan Abû Bakar, 'Umar b. al-Khațtâb, 'Uthmân b. 'Affân, dan 'Alî b. Abî Tâlib. ${ }^{23}$ Doktrin semakna juga terdapat dalam pemikiran al-Banjari, sebagaimana yang dituliskannya bahwa: "keyakinan lain selain Ahl al-Sunnah wa al-Jamâ'ah seperti kaum-kaum yang berasal dari Râfiḍah yang berpendapat bahwa Abû Bakar, 'Umar b. al-Khattâb, dan 'Uthmân adalah kafir karena telah menerima jabatan khalifah dan merampasnya dari Ali". ${ }^{24}$ Pendapatnya yang berbunyi: "iktikadnya menafikan al-sirât, hisâb, dan mîâan, maka iktikad yang demikian itu kufur.,"25

Demikian ideologi Sunnî yang dibangun oleh al-Banjari ketika menjelaskan keimanan yang benar di antara aliran keagamaan yang ada dalam Islam. Berikut dijelaskan lebih lanjut bagaimana ia menggunakan ideologi yang sama dalam menjawab tradisi lokal yang berkembang di masyarakat Banjar saat itu.

b. Tauhid Sunnî vis-a-vis Budaya Lokal

Dalam kitab Tuhfat al-Râghibîn selain menjelaskan keimanan, alBanjari juga menjawab tradisi lokal yang berkembang pada masa itu, yaitu mayanggar banua, mambuang pasilih, dan ilmu muwakkal.

1. Respons Muhammad Arshad al-Banjari terhadap Ritual Manyanggar Banua dan Mambuang Pasilib.

Sebelum memberikan penilaian terhadap tradisi manyanggar banua dan mambuang pasilih, al-Banjari terlebih dahulu menjelaskan makna bid'ah, dengan merujuk kepada pemahaman kalangan Shâfiî̀yah, seperti 'Izz al-Dîn b. 'Abd al-Salâm dan Imam Nawawî. Menurutnya, bid'ah adalah mengadakan aktivitas yang tidak terdapat dalam ajaran

${ }^{21}$ Ibn 'Asâkir al-Dimashqî, Tabyîn Kidhb al-Muftarâ fî̀ mâ Nusib ilâ al-Imâm Abî alHasan al-Ash' 'arî (Damaskus: al-Tawfìq, 1347), 150-151.

22 al-Banjari, Tuhfat al-Râghibîn, 31-32.

${ }^{23}$ Secara lebih detail bisa dilihat dalam 'Abd al-Qâhir al-Baghdâdî, al-Farq bayn alFiraq (Kairo: Maktabat Dâr al-Turâth, t.th.), 347-81.

24 al-Banjari, Tuhfat al-Râghibîn, 16.

25 Ibid., 22. 
yang dibawa oleh Nabi Muhammad, baik berupa keyakinan ataupun perbuatan. Dia juga mengutip langsung pendapat Imam Shâfi î tentang hal ini, yang mengatakan bahwa bid'ah dalâlah adalah semua perbuatan yang bertentangan dengan al-Qur'ân, hạâth, pendapat para sahabat, dan ijmấ ulama. ${ }^{26}$

Berdasarkan pendapat Imam Shâfîi ini, al-Banjari menilai bahwa dua tradisi, manyanggar banua dan mambuang pasilih, bertentangan dengan ajaran Islam, dan termasuk bid'ah dalalah. ${ }^{27}$ Penolakan alBanjari terhadap tradisi di atas masih dalam lingkup ideologi Sunnî. Hal ini bisa dilihat dari referensi yang digunakannya yakni fiqh mazhab Shâfi'iyah.

2. Respons Muhammad Arshad al-Banjari terhadap Ilmu Muwak.kal

Ilmu muwakkal adalah salah satu ilmu yang digandrungi oleh sebagian masyarakat Banjar. Dengan ilmu ini, seseorang akan bersahabat dengan jin. Jin ini akan membantunya mengetahui hal-hal gaib sehingga seseorang terlihat sakti. Menurut al-Banjari, bersahabat dengan jin sama dengan bersahabat dengan orang fasik. Pendapatnya ini secara dominan masih merujuk kepada tokoh-tokoh Sunnî meskipun ada juga yang merujuk kepada tokoh lain, seperti Shaykh 'Abd al-Wahhâb al-Sha'rânî dengan Kashf al-Hịâhb 'an Wajh al-As'ilat al-Jann, pemikir tasawuf dari tradisi Arab-Afrika (Mesir) dan Ibn 'Arabî dengan al-Futûhât al-Makkêyah, pemikir tasawuf dari tradisi Arab-Persia, dan Ibrâhîm al-Laqqânî dengan kitab Umdah al-Murîd: Sharḅ Jawhar al-Tawhîd, pemikir fiqh dari tradisi Mâlikîyah. Oleh karena itu, ideologi Sunnî-lah yang paling berperan dalam pemahaman keagamaan al-Banjari, terutama dalam kitab Tuhfat alRâghibin ini.

\section{Implikasi Ideologi Sunnî Tuḥfat al-Râghibîn}

a. Terpeliharanya Hubungan antara Kerajaan Aceh dan Kerajaan Banjar

Pada abad ke-17, menurut Zafri Zamzam, hidup seorang tokoh bernama Shaykh Ahmad Syamsuddin al-Banjari. Dia telah menyusun sebuah kitab ilmu tasawuf tentang "Asal Kejadian Nur Muhammad".

26 'Izzat 'Alî 'Aṭ̂yah, al-Bid'ah: Taḥdîduhâ wa Mawqif al-Islâm minhâ (Beirut: Dâr alKitâb al-'Arabî, t.th.), 160.

${ }^{27}$ al-Banjari, Tuhfat al-Râghibîn, 34-35. 
Saat itu kitab ini dihadiahkan pengarangnya kepada Ratu Aceh. ${ }^{28}$ Pengiriman teks itu ke kerajaan Aceh paling tidak mengindikasikan adanya hubungan yang baik antara kerajaan Aceh dan kerajaan Banjar.

Pada saat itu kerajaan Aceh memiliki pengaruh signifikan bagi keberagamaan masyarakat Banjar apalagi Aceh merupakan salah satu pembentuk konsep kekuasaan di tanah Banjar. Menurut Moh. Najib, konsep kekuasaan Banjar dipengaruhi oleh dua sistem kekuasaan, yakni kekuasaan Jawa dan kekuasaan Sumatera. ${ }^{29}$ Bentuk kekuasaan Jawa terlihat ketika kerajaan Banjar masih bernama Negara Dipa dan Negara Daha yang memiliki kecenderungan kepada agama Hindu. ${ }^{30}$ Sementara kekuasaan Sumatera terlihat ketika agama Islam tumbuh dan menyebar di daerah ini dengan pesat. ${ }^{31}$ Hasil pertemuan dua konsep kekuasaan tersebut pada akhirnya melahirkan suatu konsep kekuasaan baru yang disebut sebagai kebudayaan sungai. ${ }^{32}$

Secara ekonomi dan bisnis, masyarakat Banjar pada masa itu selain memuliakan orang yang berilmu agama juga menjadikan profesi dagang sebagai profesi yang terhormat, sehingga banyak bangsawan, ulama, dan masyarakat umumnya berusaha menjalankan profesi ini. Sementara salah satu jalur perdagangan internasional saat itu mesti melewati wilayah kekuasaan Aceh, yakni India, Singapura, Aceh, Sunda Kecil, Gresik, Bali, dan Maluku. Meskipun pada perkembangan selanjutnya, jalur perdagangan itu berubah menjadi Tiongkok, India, Singapura, Banten, Banjarmasin, Makassar, Maluku atau India, Pattani, Banjarmasin, Makassar, Maluku, ${ }^{33}$ hubungan dagang Aceh dengan Banjar tentu tidak bisa dinafikan sehingga pengaruh Aceh

28 Tim Editor, Sejarah Banjar (Banjarmasin: Pemerintah Provinsi Kalimantan Selatan, 2003), 124.

${ }^{29}$ Konsep kekuasaan Jawa berdasarkan pada budaya politik negara agraris dengan kecenderungan masyarakatnya tunduk (abdi) kepada negara. Lihat Kuntowijoyo, Paradigma Islam: Interpretasi untuk. Aksi (Bandung: Mizan, 1991), 219. Sementara konsep kekuasaan Sumatera berdasarkan pada budaya politik negara maritim yang masyarakatnya cenderung bebas dan independen. Lihat van Leur, Indonesia Trade Society: The Hague (Bandung: W. van Hoeve Ltd, 1985), 104-107.

${ }^{30}$ Idwar Saleh, Sekilas Mengenai Daerah Banjar dan Kebudayaan Sungainya (Banjarmasin: P \& K Kal-Sel, 1974), 11.

31 Saifuddin Zuhri, Sejarah Kebangkitan Islam dan Perkembangannya di Indonesia (Bandung: PT. al-Ma'arif, 1981), 401.

32 Moh. Najib, et al., Demokrasi dalam Perspektif Budaya Nusantara (Yogyakarta: LKPSMNU, 1996), 97.

33 Ramli Nawawi, "Shaykh Muhammad Arshad al-Banjari Penyebar Ahlussunnah wal Jamaah Pada Abad ke-18 di Kalimantan Selatan" (Skripsi--IAIN Antasari Banjarmasin, 1977), 20-23. 
sebagai salah satu kerajaan Islam terbesar di Nusantara tentu memiliki dampak ke tanah Banjar. ${ }^{34}$

Selain itu, Aceh juga merupakan terminal bagi jemaah haji yang akan berangkat ke Tanah Suci atau bagi mereka yang kembali ke tanah air, sebab Aceh selain merupakan pelabuhan terakhir Nusantara juga memiliki hubungan baik dengan Haramain. Menurut Azyumardi Azra, Aceh pada masa itu memiliki hubungan yang cukup kuat dengan Mekkah dan Madinah. Salah satu bukti hubungan baik antara Aceh dan Haramain adalah diberikannya stempel emas Baitul Haram kepada 'Ala' al-Din (Alaradim), Sultan Aceh, dan sejak 1570-an Aceh secara reguler menerima ulama terkemuka dari Hijaz, Mesir dan Gujarat. ${ }^{35}$

Menurut Martin, sebelum ada kapal api, perjalanan haji harus dilakukan dengan perahu layar yang sangat tergantung kepada musim. Para jemaah haji ini menumpang kapal dagang, dan ini menjadikan mereka sering berpindah kapal. Perjalanan mereka melalui berbagai pelabuhan di Nusantara berakhir di Aceh sebelum berangkat ke India lalu ke Hadramaut, Yaman atau langsung ke Jeddah. ${ }^{36}$ Kemungkinan selama mereka berada di Aceh, mereka mengikuti kegiatan-kegiatan yang bersifat keagamaan ataupun mengikuti pengajian-pengajian yang berkembang di Aceh saat itu.

Oleh karena itu, wajar saja ketika aliran wujûdîah berkembang pesat di wilayah Aceh, kerajaan Banjar pun terkena pengaruhnya terutama pada masa sebelum pulangnya al-Banjari dari Mekkah. Ketika pemikiran keagamaan di Aceh menekankan faham Sunnî dengan titik tekan pada pengembangan hukum fiqh menurut mazhab

\footnotetext{
34 Menurut Teungku Saifullah, perkembangan filsafat Islam di Aceh mengalami zaman keemasan pada awal abad ke-17 M. dan ke-18 M., yaitu sejak pemerintahan dikendalikan oleh Sultan Iskandar Muda (1607-1636) dan Shaykh Syamsuddin alSumatrani (w. 1630) dipilih sebagai penasehat dan mufti (disebut Shaykh al-Islam). Pada masa ini juga, Aceh dikenal dengan empat ulama besarnya di Nusantara, yakni Hamzah Fansuri (wafat sebelum tahun 1016/1607), Syamsuddin al-Sumatrani (w. 1630), Nurudin al-Raniri (w. 1068/1658), dan Abdul Rauf al-Singkili (1024/16151105/1693). Oleh karena itu, Aceh menjadi pusat belajar dan menimba ilmu para ulama yang datang dari berbagai negeri. Lihat dalam Teungku Saifullah, "Aceh Sebagai Pusat Pengembangan Filsafat Islam di Nusantara", dalam www. staialMuslim.blogspot.com., (14 Febuari 2014).

35 Azyumardi Azra, Jaringan Ulama Timur Tengah dan Kepulauan Nusantara Abad XVII dan XVII (Bandung: Mizan, 1995), 55.

36 Martin van Bruinessen, "Mencari Ilmu dan Pahala di Tanah Suci: Orang Nusantara Naik Haji”, dalam www.hum.uu.nl (14 Maret 2014), 6.
} 
Shâfíî, di bawah pimpinan Nuruddin al-Raniri, perkembangan keagamaan masyarakat Banjar pun ikut berubah, meskipun pada awalnya perubahan ini tidak terlalu signifikan kecuali sesudah kedatangan al-Banjari. Hal ini terjadi, karena awalnya masyarakat tidak bisa memahami referensi yang dipegang secara luas saat itu, yakni kitab Șirât al-Mustaqîm karya Nuruddin al-Raniri. ${ }^{37}$

Untuk mengatasi hal ini, al-Banjari melakukan penulisan kitab dan risâlah agama yang lebih mudah dipahami oleh masyarakat Banjar dan ia pun melakukan pembentukan kader-kader agama yang bernuansa Sunnî sebagaimana konsep dasar pikirannya pada kitab Tubfat alRâghibin.

Pengaruh Aceh yang lain terhadap intelektual Islam di Kalimantan Selatan pada abad ke-17 dan ke-18 bisa juga dilihat dari penemuan naskah "Sari Kitab Barencong" oleh Humaidy dan kawan-kawan di Nagara. Naskah ini berisi kompilasi yang dijilid menjadi satu. Dalam naskah itu ditemukan beberapa penulis Aceh seperti Hamzah Fansuri, Abdul Rauf al-Sinkili, dan Nurruddin al-Raniri. ${ }^{38}$ Oleh karena itu, perkembangan keberagamaan di Banjar tidak bisa dilepaskan dari pengaruh Aceh, termasuk perkembangan keberagamaan dalam paradigma Sunnî ini. Ini tentu saja menunjukkan adanya hubungan baik antara kerajaan Banjar dan kerajaan Aceh saat itu.

b. Dasar Paradigma Tulisan Lain Muhammad Arshad al-Banjari

Jika ditelaah dari berbagai karya Muhammad Arshad al-Banjari, maka kitab Tuhfat al-Râghibîn dan Ușul al-Dîn adalah dua kitab tauhid pertama yang dikarang olehnya ketika kembali dari tanah suci Mekkah. Namun Tuhfat al-Râghibîn-lah yang menjadi paradigma dasar dari seluruh tulisan selanjutnya, sebab kitab ini ditujukan untuk kalangan intelektual dengan argumentasi yang lebih detail dibandingkan dengan kitab Ușûl al-Dîn yang ditujukan untuk kalangan masyarakat awam sehingga bersifat praktis.

Untuk menemukan paradigma Sunnî yang menjadi dasar karyakarya al-Banjari lainnya, ada baiknya kita memperhatikan juga dua kitab lainnya yang juga memiliki pengaruh kuat dalam bidang fiqh dan tasawuf pada masyarakat Banjar.

\footnotetext{
37 A. Gazali Usman, Kerajaan Banjar: Perkembangan Politik Ekonomi Perdagangan dan Agama Islam (Banjarmasin: Lambung Mangkurat Press, 1998), 132-133.

38 Rahmadi dan Husaini Abbas, Islam Banjar: Geneologi dan Referensi Intelektual dalam Lintasan Sejarah (Banjarmasin: Antasari Press, 2012), 15-16.
} 
Dalam bidang fiqh, al-Banjari sebenarnya telah menulis beberapa kitab seperti kitab tentang nikah (Kitâb al-Nikâh), kitab tentang haid (Luqat al-'Ajlân) dan lain sebagainya, namun ia lebih dikenal dengan karya besarnya, yakni kitab Sabîl al-Mubtadîn. Kitab Sabîl al-Mubtadîn ditulis pada tahun 1193 H./1779 M., lima tahun sesudah ditulisnya kitab Tuhfat al-Râgbibîn, sebab kitab Tuhfat al-Râghibîn ditulis pada tahun 1188 H./1774 M. Kitab ini sangat populer di kalangan masyarakat Banjar, bahkan salah satu khazanah lokal yang paling sering diteliti. Salah seorang pengkaji intensif kitab ini adalah Asywadie Syukur. Dia berpendapat bahwa dalam penyusunan kitab ini terdapat 30 kitab rujukan dan semua kitab ini bermazhab Shâfîî. ${ }^{39}$

Dalam bidang tasawuf, al-Banjari dikenal dengan karyanya dalam bahasa Arab melayu yang berjudul Kanz al-Ma'rifah. Zurkani Jahja berpendapat bahwa kitab ini adalah kitab tasawuf Sunnî. Hal ini ditemukan dari pemikirannya yang menonjolkan sharî‘ah layaknya yang dilakukan oleh Imam al-Ghazâlî. ${ }^{40}$

Dari uraian di atas, ideologi Sunnî jelas menjadi dasar dari kitab fiqh dan tasawuf al-Banjari. Dengan demikian, bisa diasumsikan bahwa kitab Tubfat al-Râghibin telah meletakkan dasar ideologi tersebut, sebab selain kitab ini adalah kitab pertama yang dikarang oleh al-Banjari, ia juga merupakan kitab kalam (aqidah). ${ }^{41}$ Sementara,

39 M. Asywadie Syukur, "Telaah Khusus terhadap Kitab Sabilul Mubtadin Karya Shaykh Muhammad Arshad Muhammad Arshad al-Banjari” (Makalah Seminar Internasional Pemikiran Shaykh Muhammad Arshad Muhammad Arshad al-Banjari-Pusat Pengkajian Islam Kalimantan Selatan IAIN Antasari, 2003), 2.

40 Zurkani Jahja, "Pemikiran Shaykh Muhammad Arshad Muhammad Arshad alBanjari di Bidang Teologi dan Tasawuf' (Makalah Seminar Internasional Pemikiran Shaykh Muhammad Arshad Muhammad Arshad al-Banjari--Pusat Pengkajian Islam Kalimantan Selatan IAIN Antasari, 2003), 21. Lihat juga dalam Syaifuddin Sabda, "Kanz al-Ma'rifah Muhammad Arshad al-Banjari" (Penelitian Naskah Klasik--Pusat Penelitian IAIN Antasari, 2003), 199.

${ }^{41} \mathrm{Ilmu}$ kalam bisa disebut dengan beberapa nama, antara lain ilmu ushuluddin, ilmu tauhid, ilmu aqidah, dan fiqh akbar. Disebut ilmu ushuludin karena ilmu ini membahas pokok-pokok agama. Disebut ilmu tauhid karena membahas keesaan Allah. Dinamakan ilmu aqidah karena banyak membahas keimanan. Kemudian, fiqh al-akbar adalah istilah yang dikemukakan oleh Imam Abû Hanîfah. Menurutnya hukum Islam dengan istilah figh terbagi atas dua: pertama, figh al-akbar yang membahas keyakinan atau pokok-pokok agama, dan kedua, fiqh al-asghar yang membahas masalah mu'âmalah dan furû́ saja. Lihat Rosihan Anwar dan Abdul Rozak, Ilmu Kalam (Bandung: Pustaka Setia, t.th.), 13. Untuk informasi lebih detil lihat dalam Hasan Hanafí, Min al-'Aqî́dah ilâ al-Thawrah, Vol. 1 (Beirut: al-Markaz alThaqâfî al-'Arabî, 1988), 52-67. Ada juga yang menyebutnya dengan istilah teologi, 
menurut Mahmûd Shaltût, aqidah adalah pokok yang mendasari sharî‘'ah. Sharî‘ah tidak akan ada dalam Islam tanpa adanya aqidah; sebagaimana sharî́ah tidak akan berkembang kecuali di bawah naungan aqidah. ${ }^{42}$ Menurut Muḥammad al-Ghazâlî, akhlaq adalah aktualisasi dari aqidah sehingga tanpa aqidah akhlaq tidak bisa dilihat manifestasinya. Oleh karena itulah, ia berkata: aqidah yang kuat mewujudkan akhlaq yang baik dan mulia, sedang aqidah yang lemah mewujudkan akhlaq yang jahat dan buruk. ${ }^{43}$

c. Kontroversi Tragedi Abdul Hamid Abulung

Paradigma Sunnî yang ditumbuhkan al-Banjari juga memberikan pengaruh terhadap konsep tasawuf yang dianggap "tidak benar". Hal ini terlihat dari peristiwa kontroversial yang menimpa Abdul Hamid Abulung, seorang tokoh yang dianggap menganut aliran wahlat alwujûd, dan dihukum mati oleh pihak kerajaan karena aliran tasawufnya tersebut. Peristiwa ini disebut kontroversial sebab ada yang beranggapan bahwa tokoh ini sebenarnya hanya mitos, namun ada juga yang berpendapat bahwa tokoh ini benar-benar ada. Selain itu ada juga yang berpendapat bahwa tokoh ini memang ada akan tetapi hukuman mati itu bukanlah karena fatwa al-Banjari namun karena kepentingan politis saat itu.

Kelompok yang beranggapan bahwa Abulung memang benarbenar ada dan mengalami tragedi hukuman mati dengan fatwa alBanjari di antaranya adalah Asywadie Syukur. Menurutnya, Abulung termasuk dalam ajaran wujûdîah mulhid. Fatwa inilah yang melandasi Sultan Tahmidullah bin Tamjidillah menjatuhkan hukuman mati terhadap Abulung. ${ }^{44}$ Kelompok lain berpendapat bahwa Abulung memang ada akan tetapi kematiannya bukanlah karena fatwa alBanjari namun karena adanya kepentingan politis. Menurut Humaidy,

seperti William L. Resse yang mendefinisikan dengan discourse or reason concerning God. Namun, istilah ini agak kurang tepat jika diterapkan dalam Islam, sebab di dalam Islam tidak hanya membahas masalah Tuhan, tetapi juga mencakup prinsip-prinsip keimanan lain. Lihat Syamsuddin Arif, "Orientalis dan Teologi Islam: Sketsa Awal", Islamia: Majalab Pemikiran dan Peradaban Islam, Vol. 2, No. 3 (Desember 2005), 11-12. ${ }^{42}$ Maḥmûd Shaltût, Islâm 'Aqî̉ah wa Sharîah, Vol. 1 (Kairo: Dâr al-Qalam, 1966), 150.

43 Abû Ḥâmid al-Ghazâlî, 'Aqî̉dah al-Islâm (Kuwait: Dâr al-Bayân, 1970), 17.

44 M. Asywadie Syukur, Pemikiran-pemikiran Shaykh Muhammad Arshad Mubammad Arshad al-Banjari dalam Bidang Taubid dan Tasawuf (Banjarmasin: Comdes, 2009), 1617. 
Abulung sebenarnya adalah salah seorang tokoh sentral dalam kerajaan saat itu sebelum kembalinya al-Banjari dari Mekkah. Ia menjabat sebagai penasehat raja, karena ajaran tasawuf yang dominan saat itu adalah tasawuf wujûdîyah. Bahkan, menurutnya, sejak awal berdirinya kerajaan Banjar mulai dari Sultan Suriansyah (1527-1545 M./934-952 H.) sampai awal-awal pemerintahan Tahmidullah II (Pangeran Nata Dilaga 1761-1801 M./1175-1216 H.) ajaran tasawuf yang dominan adalah tasawuf wujûdîyah. Aliran ini sempat menjadi paham resmi kerajaan yang dianut oleh para sultan dan masyarakat secara keseluruhan. ${ }^{45}$ Oleh karena itu, hukuman mati terhadap Abulung dikarenakan ia adalah bagian dari rezim lama yang bisa mengganggu rezim baru, yang saat itu dipimpin oleh Sultan Tahmidullah II.

Sultan ini sebenarnya hanya pemegang kekuasaan sementara, karena putra mahkota masih belum dewasa. Namun Sultan Tahmidullah II malah membunuh putra mahkota tersebut. Abulung menentang tindakan tersebut dan membantu para pemberontak yang dipimpin oleh Pangeran Abdullah yang ingin membalas dendam. Oleh karena itulah, Abulung dihukum mati. ${ }^{46}$

Pendapat selanjutnya beranggapan Abulung adalah cerita rekaan saja, sebagaimana pendapat Steenbrink yang beranggapan bahwa cerita Abulung hanyalah cerita Shaykh Siti Jenar versi masyarakat Banjar, layaknya cerita Shaykh Siti Jenar yang merupakan versi Jawa dari kasus al-Hallâj. ${ }^{47}$ Menurut Mujiburrahman, dugaan Steenbrink belum tentu benar, namun ia sendiri masih belum menemukan buktibukti historis yang cukup kuat untuk membantahnya. ${ }^{48}$

Apapun perdebatan tentang kematian Abulung, namun di sini terlihat jelas peran paradigma Sunnî yang diusung oleh al-Banjari lewat karyanya Tuhfat al-Râghibîn pada masa itu, sehingga mampu menghadirkan berbagai penafsiran hingga saat ini.

\footnotetext{
${ }^{45}$ Humaidy, "Tragedi Datu Abdul Hamid Abulung: Manipulasi Kuasa atas Agama", Jurnal Kebudayaan Kandil, Edisi 2 Tahun I (2003), 49.

${ }_{46}$ Ibid., 56.

47 Mujiburrahman, "Memotret Tauhid Orang Banjar Melalui Penelitian", Kumpulan Makalab The $10^{\text {th }}$ Annual Conference on Islamic Studies (Jakarta: Kementerian Agama RI, 2010), 836.

48 Ibid.
} 
d. Maḥkamah Shariyyah dan Undang-undang Sultan Adam

Masa pemerintahan Sultan Tahmidullah II bin Sultan Tamjidillah, Muhammad Arshad al-Banjari melakukan gagasan yang terbilang baru yakni penerapan hukum Islam dengan membentuk lembaga mufti dan hakim. ${ }^{49}$ Pada masa al-Banjari ini memang tidak ada informasi eksplisit yang menyebutkan paradigma dasar hukum Islam ini. Paradigma ini semakin jelas di masa Sultan Adam, yakni paradigma Sunnî. Di masa mudanya, Sultan Adam pernah menjadi murid alBanjari. Saat itu, Sultan ini menetapkan suatu ketentuan hukum yang dikenal dengan nama "Undang-Undang Sultan Adam" pada 15 Muharram 1251 H./14 Mei 1835 M. $^{50}$

Dalam undang-undang ini secara eksplisit diungkapkan aliran Sunnî yang harus dipegangi oleh rakyat Banjar. Hal ini bisa dilihat dari pasal berikut "Pasal 1: Adapun perkara yang pertama aku perintahkan untuk seluruh rakyatku laki-laki dan perempuan beriktikad Ahl alSunnah wa al-Jamâ'ah...". ${ }^{1}$ Dengan demikian, peran Tubfat alRâgbibîn di sini adalah sebagai pembentuk paradigma dasar Sunnî pada perpolitikan kerajaan Banjar saat itu.

e. Punduk dalam Pagar

Salah satu pengokohan paradigma Sunnî yang dikandung Tubfat alRâghibin dan bersifat jangka panjang adalah pembentukan lembaga pendidikan Punduk $k^{52}$ dalam Pagar. Punduk dalam Pagar pada waktu itu

49 Tim Editor, Sejarah Banjar, 138. Lihat juga dalam Nor Wahidah, "Islam di Kalimantan Selatan Dilihat dari Perspektif Politik dan Pemerintahan", Jurnal Muhammad Arshad al-Banjari, Vol. 8 No. 1 (2009), 101. Menurut Abdurrahman, persiapan pembentukan Kerapatan Qadhi dan Kerapatan Qadhi Besar ini didasarkan pada laporan penelitian Eisenberger. Eisenberger sendiri mendasarkan penelitiannya pada koleksi naskah Kern, seorang ahli bahasa, sejarah, dan kebudayaan lokal Indonesia saat itu. Abdurrahman, "Undang-undang Sultan Adam dalam Perspektif Sejarah Hukum”, Jurnal Muhammad Arshad al-Banjari, Vol. 10 No. 2 (2009), 141.

${ }^{50}$ Tim Editor, Sejarah Banjar, 138.

51 Abdurrahman, "Studi tentang Undang-undang Sultan Adam 1835: Suatu Tinjauan tentang Perkembangan Hukum dalam Masyarakat dan Kerajaan Banjar pada Pertengahan Abad ke-19" (Laporan Penelitian--Perpustakaan Universitas Lambung Mangkurat, 1989), 63 dan 80.

52 Punduk adalah istilah yang unik dan berbeda dengan istilah pondok pesantren. Perbedaannya adalah pertama, punduk kemunculannya bernuansa Timur Tengah yang berakar pada tradisi lokal sementara pesantren lebih terpengaruh oleh institusi pendidikan Hindu-Budha. Kedua, punduk itu didirikan dengan kerjasama tuan guru dan masyarakat bahkan sultan yang telah memberi tanah sehingga punduk adalah milik bersama, sementara pesantren pada umumnya dimiliki oleh kiainya. Ketiga, pola kepemimpinan di punduk tuan guru tidak berkuasa mutlak namun berbagi 
merupakan lembaga favorit yang selalu diperbincangkan di seluruh pelosok Kalimantan Selatan, sebab punduk ini terkenal dengan alumni dan keberadaan ulama-ulama yang berpengaruh serta disegani masyarakat Banjar. Oleh karena itu, di masa keemasannya Punduk ini merupakan lembaga yang paling banyak didatangi orang. Bahkan, dalam buku Sejarah Banjar disebutkan bahwa dari lembaga ini muncul "sejumlah ulama besar dan terkenal yang kemudian menyebar ke seluruh penjuru Kalimantan bahkan juga sampai ke luar Kalimantan seperti Riau, Malaysia, Fatani, dan sebagainya. Umumnya mereka muncul sebagai mufti atau hakim". ${ }^{53}$

Menurut Humaidy, gagasan pendidikan yang dibangun al-Banjari di Punduk dalam Pagar adalah pendidikan berbasis ideologi Sunnî, sebagaimana yang diungkapkannya; "sudah barang tentu al-Banjarî juga menggunakan kitab-kitab yang berbahasa Arab secara langsung, terutama karya-karya ulama Shâfî̀ dalam bidang fiqh, mazhab Ahl alSunnah wa al-Jamâ'ah dalam tauhid dan tasawuf'. ${ }^{54}$ Jadi, lembaga inilah yang mampu mewakili dan terus-menerus memelihara paradigma yang dikembangkan al-Banjari sejak kedatangannya di tanah Banjar dan terangkum dengan jelas dalam kitab teologinya, Tubfat al-Râghibin. ${ }^{5}$

\section{Epistemologi dalam Kitab Tuḥfat al-Râghibîn}

1. Sumber

Jika ditelaah kitab Tuhfat al-Râghibîn maka ada tiga sumber utama yang digunakan al-Banjari untuk menjawab semua pertanyaan yang dilontarkan padanya dalam kitab tersebut, yakni al-Qur'ân, hạadith, dan referensi teks lain dari pemikir Islam. Untuk al-Qur'ân, ada sekitar 30 tujuh potong ayat yang digunakan al-Banjari dalam menjawab

kekuasaan dengan guru lain bahkan dengan guru yang berada di luar punduk, sementara di pesantren kiai cenderung berkuasa mutlak pada santrinya. Keempat, dengan karakter ketiga itu juga menunjukkan punduk cenderung inklusif sementara pesantren cenderung eksklusif. Kelima, punduk hidup bersama masyarakat sementara pesantren agak "membuat jarak" dengan masyarakat demi menjaga lingkungan pesantren dari pengaruh luar. Humaidy, "Shaykh Muhammad Arshad Muhammad Arshad al-Banjari dan Pendidikan Islam di Kalimantan Selatan", Jurnal Kebudayaan Kandil, Edisi 3, Tahun I, 2003, 45-46.

${ }^{53}$ Tim Editor, Sejarah Banjar, 138.

${ }^{54}$ Humaidy, "Shaykh Muhammad Arshad al-Banjari", 49.

55 Tim Peneliti, "Jaringan Intelektual Ulama Banjar Abad XIX dan XX: Studi tentang Proses, Pola dan Ekspansi Jaringan" (Laporan Penelitian--IAIN Antasari, Banjarmasin, 2009), 34. 
berbagai persoalan keimanan yang dibahasnya dalam kitab Tubfat alRâghibîn. Untuk hadîth, sebagai sumber utama kedua, dikutip oleh alBanjari dalam kitab Tuhfat al-Râgbibin sekitar 20 hadîth. Hadîth ini sebagian besar memiliki periwayatan yang jelas namun juga masih ada sekitar empat hadîth tanpa periwayatan yang jelas.

Untuk referensi teks dari pemikir Islam yang digunakan al-Banjari terdapat lima belas kitab, antara lain: Kitab Sharḅ 'Aqâ’id karya Sa'd alDîn al-Taftâzânî, Kitab Tuhfah karya Shaykh Ibn Hajar, Kitab Zạwâhir 'an Iftirâ' al-Kabâir karya Shaykh Ibn Hajar, Kitab Sharḥ al- 'Ubab karya Shaykh Mazjad, Kitab Asnâ al-Matâlib karya Zakarîyâ al-Anșarî, Kitab Rawdat al-Tâlib karya Ismâ'îl b. Muqrî, Kitab 'Awârif al-Ma'ârif karya Abû Najîb al-Suhrawardî, Kitab Tambîd karya Syukur Sulami, Kitab Minhaj al-'Âbidîn karya Imam al-Ghazâlî, Kitab 'Umdat al-Murîd: Sharh Jawhar al-Tawhị̂d karya Ibrâhîm al-Laqqanî, Kitab al-Yawâqit wa alJawâhir karya 'Abd al-Wahhâb al-Sha'rânî, Kitab Kashf al-Hịjâb wa alRâni 'an Wajh Mas'alah al-Jânn karya 'Abd al-Wahhâb al-Sha'rânî, Kitab Shu'bah karya 'Abd al-Wahhâb al-Sha'rânî, Kitab al-Futûhât alMakkîyah karya Muhy al-Dîn b. 'Arabî, dan Kitab Tadhkîr karya Imam Qurțubî.

Berdasarkan uraian di atas, bisa diidentifikasi bahwa sumber utama Tuhfat al-Râghibîn adalah teks, baik berupa ayat al-Qur'ân, hadîth, maupun karya intelektual Islam, sementara sumber rasional dan intuitif tidak ditemukan. Kalau pun hendak menghadirkan dua sumber di atas, maka sumber intuitif hanya bisa ditemukan dari tokoh Abû Najîb al-Suhrawardî dalam kitab 'Awârif al-Ma'ârif, Ibn 'Arabî dalam kitab al-Futûhât al-Makkîyah dan Imam al-Ghazâlî dalam kitab Minhâj al-Âbidîn. Meskipun demikian, dua kitab terakhir lebih banyak dirujuk berkaitan deskripsi tentang setan dan hubungannya dengan manusia. Sementara kitab 'Awârif al-Ma'ârif dirujuk untuk menjelaskan bagian dari kelompok Sufi Hulûlîyah yang bernama Qalandarîyah. Kelompok ini dianggap kafir oleh al-Banjari karena berupaya menafikan ibadah sharî́ah dengan alasan mereka telah mencapai kesucian diri. Dengan demikian, sumber intuitif dalam kitab ini bukanlah pengetahuan yang dianugerahkan langsung dari Tuhan, namun hanya bersifat pengetahuan tidak langsung yang diambil dari tokoh yang telah mendapatkan anugerah pengetahuan langsung dari Tuhan (pengetahuan kashfiyah). Sedangkan untuk sumber rasional digunakan sebagai pendukung nașs agar argumentasi naṣs bisa lebih 
diterima. Berkaitan dengan rasionalitas ini diuraikan pada bagian selanjutnya dalam topik fungsi rasio dalam kitab Tuḅfat al-Râghibîn.

2. Metode

Untuk mengetahui metode yang digunakan al-Banjari dalam Tubfat al-Râghibin bisa dikaji salah satunya ketika ia menyelesaikan problem ritual mayanggar banua dan mambuang pasilib. Pertama, ia menyatakan bahwa ritual lokal tersebut banyak mengandung pekerjaan munkar, di antaranya perbuatan tabdhîr, membuang-buang harta dengan membelanjakannya pada perbuatan yang diharamkan, sebab ritual tersebut menyediakan berbagai makanan (sesajen) dipersembahkan untuk nenek moyang yang telah meninggal dunia atau telah menjadi manusia gaib. Ia memberikan landasan normatif perbuatan tabdhî ini dengan Q.S. 17: 26-27, 02: 107-108, 04: 119-120, 35: 5-6, dan 36: 6061. Kedua, ia juga memberikan jawaban rasional dan normatif dalam perdebatan dengan pendukung ritual lokal tersebut. Dalam perdebatan itu, ada yang berpendapat bahwa ritual itu hanya sebab (media) selamat dari bahaya dan kesembuhan namun Allah juga yang mengaktualisasi dan mengizinkannya layaknya makanan dan api. Makanan tidak akan mengenyangkan dan api tidak akan membakar kecuali dikehendaki oleh Allah. Argumen ini dijawab oleh al-Banjari bahwa api dan makanan secara 'âdah (kebiasaan) memang membakar dan mengenyangkan sementara ritual tersebut tidak memiliki âdah (kebiasaan) menolak bahaya dan menyembuhkan. Oleh karena itu, analogi ini tidak dapat digunakan sebagai dalil aqidah.

Alasan lain dari pendukung ritual adalah mereka hendak memberi makan orang gaib dari keturunan raja. Mereka diberi makan seperti memberi makan keluarga dan teman, sehingga mereka dapat memberikan pertolongan. Al-Banjari menjawab bahwa argumen ini sangat bertentangan dengan al-Qur'ân, Sunnah, dan Ijmấ ulama, meskipun makanan (sesajen) itu dimakan oleh manusia atau binatang. Alasan selanjutnya dari pendukung ritual bahwa ritual ini dilakukan karena diinformasikan langsung oleh orang gaib melalui cerita nenek moyang dulu dan orang yang dirasuki-nya (kesurupan). Menurut alBanjari, cerita nenek moyang itu hanyalah khayalan dan ini tidak bisa dijadikan dalil aqidah. Ucapan orang yang kesurupan tidak dapat dijadikan landasan argumentasi, sebab itu adalah ucapan setan bukan manusia gaib. Menurutnya, al-Qur'ân, Sunnah, dan Ijmâr ulama menginformasikan bahwa yang bisa masuk ke dalam tubuh manusia adalah setan dan malaikat. Jika yang masuk itu adalah setan, maka 
ketika disebut nama Allah ia akan keluar dan apabila manusia lalai, maka setan pun masuk kembali. Jadi yang menyusupi itu adalah setan yang mengaku sebagai orang gaib.

Alasan lain dari pendukung ritual adalah bahwa mereka memberikan sesajen dengan niat untuk berobat dan memberi makan anjing. Menurut mereka berobat dan memberi makan anjing dibolehkan (mubâh) dalam Islam. Argumentasi ini dijawab oleh alBanjari bahwa niat tidak menghapuskan hukum haram, seperti orang yang membunuh manusia diniatkan membunuh tikus atau berzina yang diniatkan menyetubuhi istri sendiri, maka hukumnya tetap haram. Kemudian, argumentasi memberi makan setan dengan mengqiyâs-kan memberi makan anjing, dijawab oleh al-Banjari bahwa ketika memberi makan anjing biasanya dengan makanan busuk, diberikan di sembarang tempat dan tidak ada tanda-tanda menghormati anjing. Dalam ritual ini, sesajen disajikan secara istimewa dalam tempat yang khusus dan dilengkapi dengan berbagai hiasan serta diantar ke tempat tertentu. Ini menunjukkan adanya penghormatan kepada setan. Oleh karena itu, argumen ini tidak bisa diterima sebagai dalil aqidah.

Akhirnya, al-Banjari menyimpulkan bahwa hukum ritual ini tergantung pada keyakinan pelaku ritual. Jika pelaku menghalalkan ritual ini, maka hukumnya kafir (murtad). Jika pelaku tidak menghalalkan ritual ini namun menganggap bahwa ritual ini dapat menyembuhkan dan menolak bahaya, maka hukumnya juga kafir. Jika pelaku meyakini bahwa yang menolak bahaya dan menyembuhkan adalah kekuatan yang diciptakan Allah dalam ritual itu, maka hukumnya fasik, dan kekafirannya masih diperdebatkan oleh ulama.

Dari uraian di atas bisa disimpulkan bahwa metode yang digunakan adalah metode qiyâs dan ijtihad. Metode qiyâs istidlâl alshâhid 'alâ al-ghâib, misalnya, digunakan ketika menyerupakan kehidupan manusia gaib dengan manusia pada umumnya dan ketika al-Banjari menjelaskan adanya sifat fisik Tuhan (antropomorfisme) sebagaimana fisik manusia meskipun fisik Tuhan tidak bisa dideskripsikan. Dalam hal ini, al-shâhid adalah "manusia pada umumnya" dan "fisik manusia", sementara al-ghâib adalah "manusia gaib" dan "sifat fisik Tuhan". Metode ijtihad juga digunakan dalam Tuhfat al-Râghibin, sebab al-Banjari telah berhasil mengonstruksi jawaban terhadap problem lokal yang belum tersentuh sebelumnya, meskipun masih berdasarkan berbagai pendapat ulama yang telah populer. Di sisi lain, dalam metode ini masih ada rasionalitas, namun 
hanya berfungsi untuk mengokohkan argumentasi yang telah dibangun berdasarkan dalil naş yang telah disampaikan lebih dulu.

3. Fungsi Rasio

Dalam Tuhfat al-Raghibin, al-Banjari menyebutkan bahwa hakikat iman adalah bastan (sederhana) yakni cukup dengan taschiq hati. Ikrar lisan dengan dua kalimat shahâdat dianggap bukan bagian dari hakikat iman, tetapi hanya sebuah syarat untuk melakukan perbuatanperbuatan yang ada dalam hukum Islam. Meskipun begitu, ia juga berpendapat bahwa tasdíq bersifat batini, tidak diketahui, maka diperlukan suatu ikrar lisan sebagai indikasi bahwa ia telah diwajibkan untuk melaksanakan aturan-aturan yang ditetapkan oleh agama Islam.

Al-Banjari pun mengategorikan orang yang beriman secara lahir dan batin sebagai orang yang melakukan taschi hati dan ikrar lisan, dengan alasan bahwa secara batin ia dianggap beriman karena keimanannya diketahui Allah, sedangkan secara lahir keimanannya diketahui dengan ikrar lisannya.

Amal saleh, menurutnya, hanya pelengkap kesempurnaan iman, bukan rukun iman. Dengan ungkapan lain, seseorang yang beriman hati dan lisannya, namun tidak beramal saleh maka ia tetap mukmin namun imannya tidak sempurna dan dianggap melakukan kemaksiatan karena tidak melakukan amal saleh.

Secara teoretis, iman yang didasarkan pada penerimaan kabar wahyu disebut tasdîq, yakni menerima sesuatu sebagai benar atau salah dari informasi yang disampaikan oleh wahyu. Sedangkan iman yang didasarkan atas kemampuan rasio disebut dengan ma'rifah, yaitu mengenal dengan sungguh-sungguh keyakinan dan kepercayaan yang dipegang. Iman pada makna pertama tidak meniscayakan amal, sementara iman pada makna kedua mengharuskan penjabarannya dalam bentuk perbuatan (amal). ${ }^{56}$ Oleh karena itu, iman yang didukung oleh al-Banjari adalah iman dalam makna yang pertama.

Iman dalam makna ma'rifah didukung oleh Mu'tazilah, kelompok teologis yang dikenal sangat suka mengusung rasio sebagai landasan berpikirnya. Oleh karena bagian dari unsur iman adalah amal saleh, maka mereka memandang Muslim pelaku dosa besar sebagai orang yang telah merusak keimanannya. Pelaku ini mereka kategorikan sebagai tidak mukmin dan tidak pula kafir, al-manæilab bayn almanæilatayn. Dalam hal ini, karena iman yang diusungnya adalah iman

${ }^{56}$ Harun Nasution, Teologi Islam (Jakarta: UI Press, 1978), 147. 
tasdìq, maka al-Banjari tidak sepakat dengan aliran ini, dengan menyebutkan bahwa: "aliran ini adalah aliran yang tidak benar, karena aliran ini beranggapan jika seseorang telah tașdíq hati dan ikrar lisan tetapi tidak melakukan amal saleh, maka orang ini dianggap berada di antara iman dan kafir, bukan mukmin dan bukan pula kafir (almanzilab bayn al-manzilatayn)". ${ }^{57}$

Kelompok yang mendukung iman tasdîq pada umumnya berpendapat bahwa rasio tidak mampu mengetahui kewajiban melakukan kebaikan dan menjauhi larangan. Semua hal ini hanya bisa didapatkan lewat informasi relevasi. Dengan demikian, secara dominan, rasio berada di bawah relevasi sehingga fungsi rasio dalam hal ini adalah untuk menyokong kebenaran teks. Meskipun demikian, al-Banjari sebenarnya masih memberikan apresiasi dan peluang bagi perkembangan dan keseimbangan rasio dan relevasi.

\section{Argumentasi Defensif-Apologetik}

Islam mulai berkembang di Kalimantan Selatan sekitar abad ke-16 M., bersamaan dengan didirikannya kerajaan Islam Banjar oleh Sultan Suriansyah (1525-1550 M./931-957 H.). ${ }^{58}$ Pada masa selanjutnya perkembangan Islam di tanah Banjar cukup maju namun masih belum masif dan intensif. Keyakinan-keyakinan lokal dan pengaruh HinduBudha masih marak dipraktikkan masyarakat Banjar. Pada abad ke-18, Islam di tanah Banjar, memunculkan warna yang berbeda dan tersebar sangat masif ketika al-Banjari aktif mendakwahkannya.

Dalam dakwahnya, al-Banjari menggunakan argumentasi defensifapologetik. Argumentasi seperti ini sering digunakan pada masyarakat yang masih lemah dalam memahami suatu keyakinan, seperti masyarakat Banjar yang saat itu masih lemah dalam memahami Islam. ${ }^{59}$ Dalam konteks al-Banjari, argumentasi ini bisa dipahami sebagai upaya menunjukkan kebenaran-kebenaran Islam, terutama aliran Sunnî, sambil menunjukkan kelemahan-kelemahan non-Islam atau non-Sunnî. Kelemahan non-Islam ditunjukkan ketika menjawab

\footnotetext{
${ }^{57}$ Ibid., 5.

58 Uraian singkat tentang sejarah Kerajaan Banjar bisa ditelaah dalam A. Samad Zawawi, et al., "Kesultanan Banjar", Ensiklopedi Islam (Jakarta: CV. Anda Utama, 1992), 567-573.

${ }_{59}$ Charles J. Adams ketika memetakan pendekatan keagamaan (normative or religious approach) membagi menjadi tiga, yakni: pendekatan misionaris tradisional, pendekatan apologetik, dan pendekatan irenik. Lebih jauh lihat Charles J. Adams, The Study of The Middle East (USA: Wiley-Interscience Publication, 1976), 37.
} 
problem ritual lokal dan kelemahan non-Sunnî ditunjukkan ketika menjelaskan hakikat iman dan Islam yang benar.

Bisa disimpulkan bahwa argumentasi yang dibangun oleh alBanjari dalam Tuhfat al-Râghibin adalah argumentasi defensifapologetik, sebagai upaya untuk mempertahankan ketauhidan Islam (Sunnî) dari pengaruh budaya lokal dan ajaran lain yang masih lestari.

4. Validitas

Pada bagian pertama Tuhfat al-Râghibîn, al-Banjari mengusung iman dalam makna tasdîq. Hakikat iman tașì̃ selain didasarkan pada al-Qur'ân 58: 22, 16: 106, 49: 14, juga berdasarkan kitab-kitab Ash'arîyah dan Mâturidîyah seperti Sa'd al-Dîn al-Taftâzânî dengan kitabnya Sharḥ 'Aqâid dan Tuhfah karya Ibn Hajar.

Pada bagian kedua, fî mâ yufsid al-imân, hal-hal yang merusak keimanan, ia memvalidasi berbagai argumennya selain kepada ayatayat al-Qur'ân seperti QS. 17: 26-27, 02: 107-108, 04: 119-120, 35: 5-6, 36: 60-61, dan berbagai hadîth Nabi, juga pada kitab Sharb al-Ubab karya Shaykh Mazjad, kitab Asnâ' al-Matâlib karya Zakarîyâ al-Anșânî, kitab Rawdat al-Ṭâlib karya Ismâ'îl b. Muqrî, kitab Shu'bah karya 'Abd al-Wahhâb al-Sha'rânî, kitab 'Awârif al-Ma'ârif karya Abû Najîb alSuhrawardî, kitab Tambîd karya Shukûr Sulamî, kitab Minhâj al-'Ẩbidîn karya Imam al-Ghazâlî, kitab Umdat al-Murîd: Sharh Jawhar al-Tawhîd karya Ibrâhîm al-Laqqânî, kitab al-Yawâqit wa al-Jawâhir karya 'Abd alWahhâb al-Sha'rânî, kitab Kashf al-Hịjâb wa al-Râni 'an Wajh Mas'alah al-Jânn karya 'Abd al-Wahhâb al-Sha'rânî, dan kitab al-Futûhât alMakkeîyah karya Muhy al-Dîn b. 'Arabî.

Pada bagian ketiga, tentang kemurtadan dan hukumnya, divalidasi dengan ayat al-Qur'ân 08: 38 dan hadîth Nabi, juga pemikiranpemikiran Ibn Hajar dan Shaykh Ramlî. Pada bagian keempat, tentang dosa besar dan taubat, berbagai argumentasinya divalidasi selain dengan berbagai hadîth Nabi seperti riwayat Muslim tentang larangan merampas tanah orang lain, riwayat Bukhari-Muslim tentang bersumpah dusta, dan lain sebagainya, juga dirujuk kembali pada kitab Sharh al-Ubab karya Shaykh Mazjad, kitab Asnâ al-Matâlib karya Zakarîyâ al-Anșârî, dan kitab Raw dat al-Ṭalib karya Ismâ'îl b. Muqrî.

Pada bagian tentang perbuatan hamba, al-Banjari memvalidasi berbagai uraiannya kepada pemikiran-pemikiran Ash'arîyah dengan didukung ayat-ayat al-Qur'ân 38:96, 39:24, 46:28, 18:29 dan kitab Sharh al-'Ubab karya Shaykh Mazjad. Dari seluruh uraian di atas, bisa 
disimpulkan bahwa validitas yang digunakan al-Banjari adalah pada tingkat kesesuaian realitas atau argumen dengan teks (nasss), atau minimal mendekatinya.

\section{Infisâl wa Tajwî́ sebagai Prinsip Dasar Tubfat al-Râghibîn}

Secara teoretis, hubungan Tuhan dan alam dilihat dengan dua pendapat, yaitu: alam itu qadîm (kekal) dan alam itu ḅudûth (tidak kekal). Pendapat pertama didasarkan pada argumen ontologi dan emanasi. Bagi kelompok ini wujud itu ada dua, yakni wâjib al-wujûd (wujud niscaya) dan mumkin al-wujûd (wujud mungkin). Wujud pertama adalah eksistensi yang pasti, sementara yang kedua adalah eksistensi tidak pasti, bisa ada atau tidak ada, bergantung pada wujud pertama. Wujud kedua bisa disebut juga wujud dalam potensi ${ }^{60}$ Oleh karena alam melimpah dari eksistensi Tuhan dalam kekekalan, maka semua yang melimpah dari-Nya juga kekal (qadim) termasuk alam. Namun harus dipahami bahwa kekekalan ini adalah kekal dalam waktu bukan dalam esensi.

Pendapat kedua didasarkan pada pandangan bahwa dunia tersusun dari atom-atom dan aksiden-aksiden. Aksiden-aksiden ini tidak dapat bertahan dalam dua waktu yang berturut-turut, tetapi terus menerus diciptakan oleh Allah. Atom-atom tempat melekatnya aksiden secara terus menerus juga diciptakan oleh Allah dan hanya dapat bertahan berkat aksiden perlangsungan yang diciptakan oleh Allah di dalamnya. ${ }^{61}$ Inilah yang disebut dengan teori atomisme.

Menurut atomisme, semua atom adalah sama dan tidak mungkin mendominasi pada atom lain. Atom secara bersama-sama membentuk benda, namun pada saat yang bersamaan atom independen, terpisah, sebab atom tidak bersenyawa melainkan bersinggungan. Jika atom terkumpul, maka terbentuk sebuah materi, dan jika ia bercerai atau berpindah ke atom lain, maka suatu materi akan hancur dan perpindahan atom ke yang lain akan membentuk materi lain. ${ }^{62}$ Prinsip ini meniscayakan ruang-waktu yang tidak berkesinambungan (discontinue).

${ }^{60}$ Shams Inati, "Ibn Sina", dalam History of Islamic Philosophy, Part I, Seyyed Hossein Nasr dan Oliver Leaman (eds.) (London and New York: Routledge, 1996), 240.

${ }^{61}$ Majid Fakhry, Sejarah Filsafat Islam (Jakarta: PT. Dunia Pustaka Jaya, 1983), 297. Memang dalam paham atomisme ada postulat substansi tidak akan terpisahkan dari aksiden. Lihat Muhammad 'Âbid al-Jâbirî, Bunyat al-'Aql al-'Arabî (Beirut: Markaz Dirâsât al-Waḥdah al-'Arabîyah, 1990), 193.

${ }^{62}$ Ibid. 
Akhirnya, prinsip di atas membawa konsekuensi tidak adanya kausalitas, sebab kausalitas meniscayakan bentuk relasi berkesinambungan (continue), saling bersenyawa dan memiliki gambaran yang bersifat azali. ${ }^{63}$ Prinsip yang dibangun oleh kitab Tubfat al-Râghibîn karya al-Banjari tentang hubungan Tuhan dan alam semesta berada pada prinsip infisâal (tidak berkesinambungan) ini. Hal ini bisa diidentifikasi dari pendapatnya yang mengatakan bahwa salah satu penyebab kafir atau rusaknya keimanan seseorang adalah ungkapan dan keyakinan bahwa alam itu bersifat qadìm. ${ }^{64}$

Demikian juga pada pendapatnya tentang hubungan api yang membakar dan makanan yang mengenyangkan, ketika ia menjawab problem ritual manyanggar dan mambuang pasilib. Menurutnya, api yang membakar dan makanan yang mengenyangkan hanyalah tabiat (nature) atau sifat kebiasaan ('âdab) saja. Pada prinsipnya, dua hal itu tidak akan berfungsi jika tidak dikehendaki oleh Allah. ${ }^{65}$

Berdasarkan kecenderungan prinsip metafisik hubungan Tuhan dan alam di atas, maka dapat diketahui prinsip hubungan Tuhan dan manusia yang dipegang oleh al-Banjari yakni prinsip tajwî́, serba boleh. Alasannya adalah atom maupun aksiden dipahami sangat bergantung pada tindakan kreasi Tuhan yang berkesinambungan (continue). Tanpa tindakan ini maka eksistensi keduanya nihil. Dengan demikian, otoritas ketuhanan adalah segala-galanya. Jadi, Tuhan bisa bertindak sewenang-wenang terhadap ciptaan-Nya termasuk manusia. Dia bisa mengampuni orang yang berdosa besar dan memasukkan ke dalam surga atau boleh pula Dia menyiksa orang yang berbuat baik dan memasukkan ke dalam neraka. Tuhan adalah penentu segalanya (lâ fấila illa Allâh). Berikut pendapat al-Banjari yang sesuai dengan prinsip tajwîz ini: 1) Barangsiapa berkata orang yang aniaya inilah sudah dengan takdir Allah, maka kata orang yang menganiaya: aku perbuat pekerjaan ini tiada dengan takdir Allah, maka jadi kafir orang yang menganiaya itu, ${ }^{66}$ dan 2) Setengah mereka itu adalah iktikadnya bahwa Allah tiada menghukumkan atas segala makhluk dengan suatu hukum, maka iktikad ini kufur. ${ }^{67}$

${ }^{63}$ Ibid., 193. Kritik Ibn Rushd terhadap dalil atomisme ini bisa dilihat dalam Ibid., 531-533.

${ }^{64}$ al-Banjari, Tuhfat al-Râghibin, 7-8.

${ }^{65}$ Ibid., 37-38.

${ }^{66}$ Ibid., 9.

${ }^{67}$ Ibid. Untuk ungkapan lainnya bisa dilihat pada kitab Tuhfat al-Râghibîn halaman 17-18, 21-22, dan 57. 
Berdasarkan uraian di atas, dapat dipahami bahwa prinsip dasar yang dibangun oleh al-Banjari dalam kitab Tubfat al-Râghibîn adalah prinsip infisâl wa tajwîz (tidak berkesinambungan dan serba boleh). Akhirnya, dengan memperhatikan uraian di atas, bisa dipahami bahwa karakteristik episteme yang terdapat dalam kitab Tuhfat al-Râghibin adalah epistemologi bayânî.

\section{Penutup}

Ideologi yang terkandung dalam Tuhfat al-Râghibîn adalah Sunnî dalam makna yang luas (Ash'arîyah, Mâturidîyah, dan Salafiyah). Hal ini mampu mengimplikasikan stabilitas politik global dan lokal serta menumbuhkan perkembangan intelektual dan lembaga pendidikan Islam lokal pada zamannya.

Epistemologi yang terkandung dalam Tuhfat al-Râghibîn adalah bayânî karena sumber utama yang digunakan adalah teks (nașs), metodenya adalah qiyâs dan ijtihad, peran rasio digunakan sebagai penyokong kebenaran teks, bentuk argumennya defensif-apologetik, validitasnya adalah kesesuaian realitas atau argumen dengan nass, dan prinsip dasar yang dibangunnya adalah tidak berkesinambungan dan serba boleh.

Akhirnya, satu sikap yang bisa dipelajari dari al-Banjari adalah sikap defensif-kritis dalam Tubfat al-Râghibîn. Hal ini masih bisa diaktualisir dengan mempertahankan keyakinan yang dimiliki sambil bersikap inklusif-kritis terhadap perkembangan kontemporer, sehingga bisa menghadirkan sintesa konstruktif-kreatif-unik.

\section{Daftar Rujukan}

Abdurrahman. "Studi tentang Undang-undang Sultan Adam 1835:

Suatu Tinjauan tentang Perkembangan Hukum dalam Masyarakat dan Kerajaan Banjar pada Pertengahan Abad ke-19". Laporan Penelitian--Perpustakaan Universitas Lambung Mangkurat, 1989.

----. "Undang-undang Sultan Adam dalam Perspektif Sejarah Hukum", Jurnal Muhammad Arshad al-Banjari, Vol. 10, No. 2, 2009.

Adams, Charles J. The Study of The Middle East. USA: WileyInterscience Publication, 1976.

Anwar, Rosihan., dan Rozak, Abdul. Ilmu Kalam. Bandung: Pustaka Setia, t.th.

Arif, Syamsuddin. "Orientalis dan Teologi Islam: Sketsa Awal", Islamia: Majalah Pemikiran dan Peradaban Islam, Vol. 2 No. 3, Desember 2005. 
Dimashqî (al), Ibn 'Asâkir. Tabyîn Kadhb al-Muftarâ fî mâ Nusib ilâ alImâm Abî al-Hasan al-Ash'arî. Damaskus: al-Tawfîq, 1347.

Ash'arî (al), Abû Hạan 'Alî b. Ismâ'îl. al-Ibânah 'an Usûul al-Diyânah. t.t.: Dâr al-Da'wah al-Salafiyah, 1992.

----. Kitâb al-Luma' fì al-Radd 'alâ Abl al-Ziyagh wa al-Bida' Mesir: Shirkah Mâhimah Muḍîyah, 1955.

'Aṭ̂yah, 'Izzat 'Alî. al-Bid'ah: Tahdidubâ wa Mawqif al-Islâm minhâ. Beirut: Dâr al-Kitâb al-'Arabî, t.th.

Azra, Azyumardi. Jaringan Ulama Timur Tengah dan Kepulauan Nusantara Abad XVII dan XVII. Bandung: Mizan, 1995.

Baghdâdî (al), 'Abd al-Qâhir. al-Farq bayn al-Firaq. Kairo: Maktabat Dâr al-Turâth, t.th.

----. Kitâb Usûllal-Dinn. Beirut: Dâr al-Âfâq al-Jadîdah, 1981.

Banjari (al), Shaykh Muhammad Arshad bin Abdullah. Tuhfah alRâgbibin. Martapura: YAPIDA, 2000.

Bazdawî (al), Abû al-Yasr. Usûllal-Dîn. Kairo: al-Maktabah al-Azharîyah li al-Turâth, 2003.

Editor, Tim. Sejarah Banjar. Banjarmasin: Pemerintah Provinsi Kalimantan Selatan, 2003.

Fakhry, Majid. Sejarah Filsafat Islam. Jakarta: Dunia Pustaka Jaya, 1983.

Ghazâlî (al), Abû Hâmid. 'Aqî̉ah al-Islâm. Kuwait: Dâr al-Bayân, 1970.

Hanafî, Hasan. Min al-'Aqî̉ah ilâ al-Thawrah, Vol. 1. Beirut: al-Markaz al-Thaqâfî al-'Arabî, 1988.

Humaidy. "Shaykh Muhammad Arshad Muhammad Arshad alBanjari dan Pendidikan Islam di Kalimantan Selatan". Jurnal Kebudayaan Kandil, Edisi 3, Tahun I, 2003.

----. "Tragedi Datu Abdul Hamid Abulung: Manipulasi Kuasa atas Agama", Jurnal Kebudayaan Kandil, Edisi 2 Tahun I, 2003.

Inati, Shams. "Ibn Sina", dalam History of Islamic Philosophy, Part I, Seyyed Hossein Nasr dan Oliver Leaman (eds.). London and New York: Routledge, 1996.

Jâbirî (al), Muhạmmad 'Âbid. Bunyat al-'Aql al-'Arabî. Beirut: Markaz Dirâsât al-Waḥdah al-'Arabîyah, 1990.

Jahja, Zurkani. "Pemikiran Shaykh Muhammad Arshad Muhammad Arshad al-Banjari di Bidang Teologi dan Tasawuf'. Makalah Seminar Internasional Pemikiran Shaykh Muhammad Arshad Muhammad Arshad al-Banjari--Pusat Pengkajian Islam Kalimantan Selatan IAIN Antasari, 2003. 
Kuntowijoyo. Paradigma Islam: Interpretasi untuk Aksi. Bandung: Mizan, 1991.

Mujiburrahman. "Memotret Tauhid Orang Banjar Melalui Penelitian", Kumpulan Makalah The $10^{\text {th }}$ Annual Conference on Islamic Studies. Jakarta: Kementerian Agama RI, 2010.

Najib, Moh. et al., Demokrasi dalam Perspektif Budaya Nusantara. Yogyakarta: LKPSMNU, 1996.

Nasafî (al), 'Umar b. Muḥammad. al-'Aqâid al-Nasafîyah. t.t.: t.p., 537 $\mathrm{H}$.

Nasution, Harun. Teologi Islam. Jakarta: UI Press, 1978.

Nawawi, Ramli. "Shaykh Muhammad Arshad al-Banjari Penyebar Ahlussunnah wal Jamaah Pada Abad ke-18 di Kalimantan Selatan". Skripsi--IAIN Antasari Banjarmasin, 1977.

Peneliti, Tim. "Jaringan Intelektual Ulama Banjar Abad XIX dan XX: Studi tentang Proses, Pola dan Ekspansi Jaringan". Laporan Penelitian--IAIN Antasari, Banjarmasin, 2009.

Rahmadi dan Abbas, Husaini. Islam Banjar: Geneologi dan Referensi Intelektual dalam Lintasan Sejarah. Banjarmasin: Antasari Press, 2012.

Sabda, Syaifuddin. "Kanz al-Ma'rifah Muhammad Arshad al-Banjari". Penelitian Naskah Klasik--Pusat Penelitian IAIN Antasari, 2003.

Saifullah, Teungku. "Aceh Sebagai Pusat Pengembangan Filsafat Islam di Nusantara", dalam www. stai-alMuslim.blogspot.com., 14 Febuari 2014.

Saleh, Idwar. Sekilas Mengenai Daerah Banjar dan Kebudayaan Sungainya. Banjarmasin: P \& K Kal-Sel, 1974.

Shaltût, Mahmûd. Islâm 'Aqîdah wa Sharî́ah, Vol. 1. Kairo: Dâr alQalam, 1966.

Subkî, 'Abd al-Kâfî. Tabaqât al-Shâfî̀ al-Kubrâ. Mesir: 'Îsâ Bâb alHalibi, 1964.

Syukur, M. Asywadie. "Telaah Khusus terhadap Kitab Sabilal Muhtadin Karya Shaykh Muhammad Arshad Muhammad Arshad al-Banjari”. Makalah Seminar Internasional Pemikiran Shaykh Muhammad Arshad Muhammad Arshad al-Banjari--Pusat Pengkajian Islam Kalimantan Selatan IAIN Antasari, 2003.

-----. Pemikiran-Pemikiran Shaykh Muhammad Arshad Mubammad Arshad al-Banjari dalam Bidang Taubid dan Tasawnf. Banjarmasin: Comdes, 2009. 
Taftâzânî (al), Sa'd al-Dîn. Sharḥ al-'Aqâ’id al-Nasafîyah. Kairo: Maktabah al-Kulliyât al-Azharîyah, 1988.

Usman, A. Gazali. Kerajaan Banjar: Perkembangan Politik Ekonomi Perdagangan dan Agama Islam. Banjarmasin: Lambung Mangkurat Press, 1998.

van Bruinessen, Martin. "Mencari Ilmu dan Pahala di Tanah Suci: Orang Nusantara Naik Haji", dalam www.hum.uu.nl, 14 Maret 2014.

van Leur. Indonesia Trade Society: The Hague. Bandung: W. van Hoeve Ltd, 1985.

Wahidah, Nor. "Islam di Kalimantan Selatan Dilihat dari Perspektif Politik dan Pemerintahan", Jurnal Mubammad Arshad al-Banjari, Vol. 8, No. 1, 2009.

Zawawi, A. Samad. et al., "Kesultanan Banjar", Ensiklopedi Islam. Jakarta: CV. Anda Utama, 1992.

Zuhri, Saifuddin. Sejarah Kebangkitan Islam dan Perkembangannya di Indonesia. Bandung: PT. al-Ma’arif, 1981. 